\title{
Pemetaan Fasilitas Kesehatan BPJS Kota Samarinda Studi Kasus Rumah Sakit, Puskesmas, dan Klinik Pratama
}

\author{
Nia Kurniadin* \\ Teknologi Geomatika, Politeknik Pertanian Negeri \\ Samarinda, Samarinda, 75131 \\ niakurniadin@politanisamarinda.ac.id \\ *Corresponding author \\ Arsya Farky Fadjuani \\ Teknologi Geomatika, Politeknik Pertanian Negeri \\ Samarinda, Samarinda, 75131 \\ arsyafarky@gmail.com
}

\author{
Dyah Widyasasi \\ Teknologi Geomatika, Politeknik Pertanian Negeri \\ Samarinda, Samarinda, 75131 \\ widysh1@gmail.com \\ F. V. Astrolabe Sian Prasetya \\ Teknologi Geomatika, Politeknik Pertanian Negeri \\ Samarinda, Samarinda, 75131 \\ astrolabesp@politanisamarinda.ac.id
}

\begin{abstract}
Abstrak-Sebagai Ibukota Provinsi Kalimantan Timur Samarinda memiliki jumlah penduduk yang sangat besar. BPS (Badan Pusat Stastistik) Kota Samarinda menunjukan jumlah penduduk pada tahun 2020 mencapai 886.806 jiwa. Jumlah tersebut tersebar dalam 10 Kecamatan dan 59 Kelurahan. Besarnya populasi manusia di Kota Samarinda mengakibatkan besar pula kebutuhan akan pelayanan fasilitas kesehatan khususnya Rumah Sakit, Puskesmas, dan Klinik Pratama di wilayah ini. Demikinan pula kebutuhan akan ketersediaan fasilitas kesehatan yang bekerjasama dengan BPJS Kesehatan serta kemudahan akses informasi jenis layanan yang dicover oleh BPJS Kesehatan. Tujuan dari kegiatan penelitian ini yaitu untuk memetakan lokasi Rumah Sakit, Puskesmas, dan Klinik yang menyediakan layanan BPJS Kesehatan di Kota Samarinda. Metode yang dipergunakan dalam penelitian ini adalah pengambilan data yang terdapat pada website BPJS Kesehatan, yang selanjutnya dilakukan pengambilan data koordinat dan data mengenai jenis layanan, informasi serta ketersediaan layanan BPJS yang terdapat pada fasilitas Kesehatan di Kota Samarinda. Data selanjutnya diolah menggunakan perangkat lunak SIG dengan hasil akhir berupa layout peta. Hasil pada penelitian ini menunjukan terdapat 12 dari 15 Rumah Sakit melayani pasien BPJS, 14 Puskesmas seluruhnya menyediakan layanan BPJS, serta 40 dari 49 Klinik melayani BPJS.
\end{abstract}

Kata Kunci-Fasilitas Kesehatan, BPJS, Klinik Pratama, Puskesmas, Rumah Sakit

\section{PENDAHULUAN}

Samarinda sebagai Ibukota Provinsi Kalimantan Timur memiliki jumlah penduduk yang sangat besar. Informasi yang diperoleh dari BPS (Badan Pusat Stastistik) Kota Samarinda menunjukan jumlah penduduk pada tahun 2020 mencapai 886.806 jiwa. Jumlah tersebut tersebar dalam 10 Kecamatan dan 59 Kelurahan (Anonim, 2020).
Besarnya populasi manusia di Kota Samarinda berdampak pula pada kebutuhan akan pelayanan fasilitas kesehatan dan jaminan kesehatan yang diterima masyarakat.

Fasilitas Pelayanan Kesehatan adalah suatu alat dan/atau tempat yang digunakan untuk menyelenggarakan upaya pelayanan kesehatan, baik promotif, preventif, kuratif, maupun rehabilitatif yang dilakukan oleh Pemerintah Pusat, Pemerintah Daerah dan/atau masyarakat. Untuk mencapai derajat kesehatan masyarakat yang baik, diperlukan Fasilitas Pelayanan Kesehatan yang dapat menyediakan pelayanan kesehatan yang terjangkau bagi seluruh lapisan masyarakat dalam rangka peningkatan kesehatan, pemeliharaan kesehatan, pengobatan penyakit, dan pemulihan kesehatan (Endradita, 2019). Fasilitas kesehatan yang menyelenggarakan pelayanan kesehatan antara lain Rumah Sakit, Puskesmas, dan Klinik.

Menurut Peraturam Menteri Kesehatan No. 30 Tahun 2019 tentang Klasifikasi dan Perizinan Rumah Sakit, Rumah Sakit adalah institusi pelayanan kesehatan yang menyelenggarakan pelayanan kesehatan perorangan secara paripurna yang menyediakan pelayanan rawat inap, rawat jalan, dan gawat darurat (Permenkes, 2019). Permenkes 43 tahun 2019 tentang Puskesmas menyebutkan bahwa Puskesmas adalah Fasilitas Pelayanan Kesehatan (Faskes). Fasilitas Pelayanan Kesehatan adalah suatu tempat yang digunakan untuk menyelenggarakan upaya pelayanan kesehatan, baik promotif, preventif, kuratif maupun rehabilitatif yang dilakukan oleh pemerintah, pemerintah daerah dan/atau masyarakat. Puskesmas mempunyai tugas melaksanakan kebijakan kesehatan untuk mencapai tujuan pembangunan kesehatan di wilayah kerjanya (Anonim, 2021). Permenkes 9 Tahun 2014 tentang Klinik menyatakan bahwa Klinik adalah fasilitas pelayanan kesehatan yang menyelenggarakan pelayanan kesehatan perorangan yang menyediakan pelayanan medis dasar dan/atau spesialistik (PKFI, 2014). 
Demikian halnya dengan jaminan kesehatan yang diterima masyarakat, keberadaan fasilitas kesehatan yang bekerjasama dengan BPJS Kesehatan dalam memberikan layanan kepada masyarakat menjadi kebutuhan yang tidak dapat dipisahkan seiring dengan meningkatnya jumlah penduduk di Kota Samarinda. Keberadaan informasi yang dapat diakses oleh masyarakat melalui jaringan internet dan website baik milik pemerintah maupun media sosial sangat membantu masyarakat dalam mendapatkan sumber informasi. Namun masih dijumpai ketidakmutakhiran data yang disajikan sehingga masih ada beberapa fasilitas kesehatan yang tidak termasuk dalam informasi yang disajikan dan/atau fasilitas kesehatan yang sudah tidak melayani BPJS namun masih terdata sebagai fasilitas kesehatan yang melayani BPJS.

Beberapa penelitian tentang sebaran fasilitas kesehatan telah dilakukan oleh beberapa peneliti. Di antaranya penelitian Rita (2012) Sistem Informasi Geografis Puskesmas Induk Kota Samarinda, penetlitian Rahardjo \& Sugiyanto (2015) Sistem Informasi Geografis Pemetaan Fasilitas Kesehatan Pada BPJS Kota Semarang, penelitian Putri et al. (2017) Sistem Informasi Pemetaan Fasilitas Kesehatan BPJS Berbasis Android di Kota Bitung, penelitian Melya (2017) Analisis dan Pemetaan Sebaran Fasilitas Kesehatan di Kabupaten Lampung Barat, dan penelitian Dani (2017) Persebaran Rumah Sakit di Kota Samarinda Berbasis Website.

Adanya perbedaan data yang disajikan oleh beberapa penyedia informasi dan beberapa penelitian terdahulu tentang pemetaan sebaran fasilitas kesehatan, dipandang perlu dilakukan penelitian untuk memetakan fasilitas kesehatan yang melayani BPJS dengan data yang mutakhir. Penelitian ini bertujuan untuk mengetahui jumlah fasilitas kesehatan yang melayani, mengetahui informasi jenis layanan dan ketersediaan layanan BPJS Kesehatan, serta menyediakan peta sebaran Rumah Sakit, Puskesmas, dan Klinik Pratama yang melayani BPJS Kesehatan di Kota Samarinda.

\section{Metodologi}

\section{A. Lokasi Penelitian}

Lokasi penelitian ini adalah Kota Samarinda dengan objek penelitian adalah Fasilitas Kesehatan yang menyelenggarakan pelayanan BPJS Kesehatan yang terdiri dari Rumah Sakit, Puskesmas, dan Klinik Pratama di Kota Samarinda. Pengolahan data dilakukan di Laboratorium Geomatika Program Studi Teknologi Geomatika Politeknik Pertanian Negeri Samarinda.

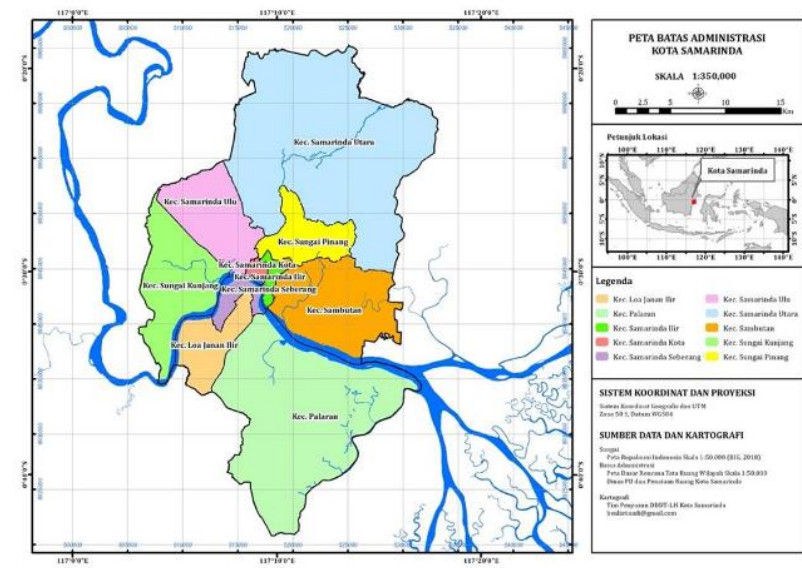

Gambar 1. Lokasi Penelitian

\section{B. Data dan Peralatan}

Data yang digunakan dalam penelitian ini adalah data Fasilitas Kesehatan di Kota Samarinda yang terdiri dari Rumah Sakit, Puskesmas, dan Klinik Pratama. Data penelitian berupa titik koordinat yang diperoleh dari hasil pengukuran di lapangan dan data Nama dan Alamat Fasilitas Kesehatan yang diperoleh dari website BPJS Kesehatan Kota Samarinda.

Perangkat keras yang digunakan dalam penelitian ini adalah GPS Garmin 64s sebagai alat untuk mengambil data koordinat, dan kamera digital untuk dokumentasi penelitian. Sedangkan perangkat lunak yang digunakan adalah Mapsource untuk memindahkan data koordinat dari GPS ke komputer, dan ArcGIS untuk mengolah data penelitian dan pembuatan layout peta.

\section{Tahap Pengumpulan dan Pengolahan Data}

Peoses pengumpulan data yang terdiri atas data koordinat dan nama serta alamat fasilitas kesehatan yang melayani BPJS. Data nama dan alamat fasiliitas kesehatan diperoleh dari laman website BPJS Kota Samarinda, sedangkan data koordinat fasilitas kesehatan diperoleh dengan cara mengunjungi masing-masing fasilitas kesehatan dan melakukan marking menggunakan GPS Garmin 64s. Hasil pengambilan data dilapangan kemudian dimasukkan ke dalam formulir data fasilitas kesehatan seperti yang disajikan pada Tabel 1, berikut ini.

Tabel 1. Formulir Data Fasilitas Kesehatan

\begin{tabular}{|c|c|l|c|c|c|c|}
\hline \multirow{2}{*}{ No } & Nama & \multirow{2}{*}{ Status } & \multicolumn{2}{|c|}{ Koordinat } & \multirow{2}{*}{ Alamat } & \multirow{2}{*}{ Kec. } \\
\hline & Faskes & & $\mathrm{X}$ & $\mathrm{Y}$ & & \\
\hline 1 & & & & & & \\
\hline 2 & & & & & & \\
\hline 3 & & & & & & \\
\hline 4 & & & & & & \\
\hline$\ldots$ & & & & & & \\
\hline
\end{tabular}

Data hasil marking koordinat fasilitas kesehatan menggunakan GPS handheld selanjutnya diunduh ke komputer menggunakan perangkat lunak Mapsource. Data tersebut selanjutnya diolah menggunakan ArcGIS dan disajikan dalam bentuk peta dan Sistem Informasi Geografis sebaran fasilitas kesehatan penyelenggara layanan BPJS di Kota Samarinda. 


\section{HASIL DAN PEMBAHASAN}

Data fasilitas kesehatan penyelenggaran layanan BPJS Kesehatan yang tersebar di Kota Samarinda telah berhasil dikumpulkan berdasarkan data lapangan dan data dari website BPJS Kesehatan. Dari data yang diperoleh, terdapat 15 Rumah Sakit dengan 12 diantaranya melayani peserta BPJS Kesehatan, 24 Puskesmas melayani peserta PBJS Kesehatan, dan 49 Klinik Pratama dengan 40 diantaranya melayani peserta BPJS Kesehatan. Data fasilitas kesehatan selengkapnya disajikan pada Tabel 2, Tabel 3, dan
Tabel 4.

Data fasilitas kesehatan tersebut tersebar di 10 kecamatan yang ada di Kota Samarinda. Sebaran fasilitas kesehatan pada masing-masing kecamatan tidak merata, baik dari segi jumlah maupun sebaran secara spasial. Keberadaan fasilitas kesehatan tersebut terpusat pada daerah dengan kepadatan penduduk tinggi dan pada pusat-pusat kegiatan masyarakat, seperti perkantoran dan sekolah atau universitas. Data sebaran jumlah fasilitas kesehatan di Kota Samarinda disajikan pada Gambar 2 berikut ini.

Tabel 2. Data Rumah Sakit di Kota Samarinda

\begin{tabular}{|c|c|c|c|c|c|c|}
\hline \multirow{2}{*}{ No } & \multirow{2}{*}{ Nama Faskes } & \multirow{2}{*}{ Status } & \multicolumn{2}{|c|}{ Koordinat } & \multirow{2}{*}{ Alamat } & \multirow{2}{*}{ Kecamatan } \\
\hline & & & $\mathrm{X}(\mathrm{m})$ & Y (m) & & \\
\hline 1 & RS I. A. Moeis & BPJS & 512376.819 & 9938207.923 & JL. H.A.M. Rifaddin & Loa Jana Ilir \\
\hline 2 & RS Siaga & BPJS & 515813.947 & 9947617.010 & JL. Ramania & Samarinda Ulu \\
\hline 3 & RSUD A.W. Syahrani & BPJS & 516177.522 & 9947062.307 & JL. Palang Merah & Samarinda Ulu \\
\hline 4 & RS Dirgahayu & BPJS & 515191.029 & 9944859.468 & JL. Gunung Merbabu & Samarinda Ulu \\
\hline 5 & RS Hermina & BPJS & 512130.687 & 9943952.369 & JL. Teuku Umar & Sungai Kunjang \\
\hline 6 & RS SMC & BPJS & 513876.846 & 9947721.762 & JL. Kadri Oneng & Samarinda Ulu \\
\hline 7 & RS Bhakti Nugraha & BPJS & 516363.758 & 9945193.529 & JL. Basuki Rahmat & Samarinda Kota \\
\hline 8 & RSJ Atma Husada Mahakam & BPJS & 517715.715 & 9944062.241 & JL. Gurami & Samarinda Ilir \\
\hline 9 & RS Tentara TK. IV Samarinda & BPJS & 515901.182 & 9944610.443 & JL. Jend. Sudirman & Samarinda Kota \\
\hline 10 & RSIA Aisyiyah & BPJS & 517125.437 & 9944546.542 & JL. Pangeran Hidyatullah & Samarinda Kota \\
\hline 11 & RSIA Qurrata Ayun & BPJS & 520390.132 & 9948903.776 & JL. D.I. Panjatan & Sungai Pinang \\
\hline 12 & RS Korpri & BPJS & 516725.013 & 9945569.653 & JL. Kesuma Bangsa & Samarinda Kota \\
\hline 13 & RSIA Herawati & Non BPJS & 512923.336 & 9942273.073 & JL. Untung Suropati & Sungai Kunjang \\
\hline 14 & $\begin{array}{l}\text { RS Bersalin Ria Kencana } \\
\text { PKBI }\end{array}$ & Non BPJS & 515795.971 & 9947717.878 & JL. Letnan Jend. Suprapto & Samarinda Ulu \\
\hline 15 & RS Haji Darjad & Non BPJS & 516526.254 & 9945281.333 & JL. Dahlia & Samarinda Kota \\
\hline
\end{tabular}

Tabel 3. Data Puskesmas di Kota Samarinda

\begin{tabular}{|c|c|c|c|c|c|c|}
\hline \multirow{2}{*}{ No } & \multirow{2}{*}{ Nama Faskes } & \multirow{2}{*}{ Status } & \multicolumn{2}{|c|}{ Koordinat } & \multirow{2}{*}{ Alamat } & \multirow{2}{*}{ Kecamatan } \\
\hline & & & $\mathrm{X}(\mathrm{m})$ & $\mathrm{Y}(\mathrm{m})$ & & \\
\hline 1 & Puskesmas Loa Bakung & BPJS & 510183.261 & 9941510.409 & JL. Jakarta & Sungai Kunjang \\
\hline 2 & Puskesmas Karang Asam & BPJS & 513075.519 & 9943613.113 & JL. Slamet Riyadi & Sungai Kunjang \\
\hline 3 & Puskesmas Baqa & BPJS & 515774.517 & 9943618.380 & JL. Ia. Madu Keleng & $\begin{array}{l}\text { Samarinda } \\
\text { Seberang }\end{array}$ \\
\hline 4 & Puskesmas Harapan Baru & BPJS & 511646.06 & 9939995.508 & JL. Kurnia Makmur & Loa Janan Ilir \\
\hline 5 & Puskesmas Juanda & BPJS & 514996.879 & 9947519.903 & JL. Juanda & Samarinda Ulu \\
\hline 6 & Puskesmas Segiri & BPJS & 516012.033 & 9947131.213 & JL. Ramania II & Samarinda Ulu \\
\hline 7 & Puskesmas Pasundan & BPJS & 515289.943 & 9945238.134 & JL. Pasundan & Samarinda Ulu \\
\hline 8 & Puskesmas Wonorejo & BPJS & 513951.785 & 9944987.240 & JL. Cendana & Sungai Kunjang \\
\hline 9 & Puskesmas Air Putih & BPJS & 513562.591 & 9947566.125 & JL. Pangeran Suryanata & Samarinda Ulu \\
\hline 10 & Puskesmas Sempaja & BPJS & 517146.134 & 9950104.006 & JL. P.M. Noor & $\begin{array}{l}\text { Samarinda } \\
\text { Utara }\end{array}$ \\
\hline 11 & Puskesmas Lok Bahu & BPJS & 509577.602 & 9945444.745 & JL. M. Said & Sungai Kunjang \\
\hline 12 & Puskesmas Bengkuring & BPJS & 518058.138 & 9952778.400 & JL. Bengkuring Raya & $\begin{array}{l}\text { Samarinda } \\
\text { Utara }\end{array}$ \\
\hline 13 & Puskesmas Sidomulyo & BPJS & 517942.621 & 9944633.614 & JL. Jelawat & Samarinda Ilir \\
\hline 14 & Puskesmas Remaja & BPJS & 518405.091 & 9947301.943 & JL. Remaja & Samarinda Kota \\
\hline 15 & Puskesmas Samarinda Kota & BPJS & 516056.945 & 9945235.627 & JL. Bhayangkara & Samarinda Kota \\
\hline 16 & Puskesmas Sambutan & BPJS & 522153.308 & 9943198.027 & JL. Pelita 6 & Sungai Pinang \\
\hline 17 & Puskesmas Trauma Center & BPJS & 509768.930 & 9937395.143 & JL. Cipto Mangunkusumo & Loa Janan Ilir \\
\hline 18 & Puskesmas Lempake & BPJS & 521193.594 & 9949758.107 & JL. D.I Panjaitan & Sungai Pinang \\
\hline 19 & Puskesmas Palaran & BPJS & 520142.234 & 9937307.857 & JL. Bhayangkara Palaran & Palaran \\
\hline 20 & Puskesmas Makroman & BPJS & 524911.734 & 9938440.511 & JL. Sekolahan & Sambutan \\
\hline 21 & Puskesmas Batuas & BPJS & 523297.101 & 9928365.772 & JL. Al-Hasnie & Sambutan \\
\hline 22 & Puskesmas Sungai Kapih & BPJS & 518801.335 & 9941168.118 & JL. Kesehatan BLK & Sambutan \\
\hline 23 & Puskesmas Temindung & BPJS & 518288.094 & 9946355.344 & JL. Pelita & Sungai Pinang \\
\hline 24 & Puskesmas Bukuan & BPJS & 522319.097 & 9936416.762 & JL. Manggis & Palaran \\
\hline
\end{tabular}


Buletin Poltanesa Vol. 22 No. 2 (Desember 2021) p-ISSN 2721-5350 e-ISSN 2721-5369 https://doi.org/10.51967/tanesa.v22i2.885 @ 2021 Politeknik Pertanian Negeri Samarinda This work is licensed under a Creative Commons Attribution-ShareAlike 4.0 License

Tabel 4. Data Klinik Pratama di Kota Samarida

\begin{tabular}{|c|c|c|c|c|c|c|}
\hline \multirow{2}{*}{ No } & \multirow{2}{*}{ Nama Faskes } & \multirow{2}{*}{ Status } & \multicolumn{2}{|c|}{ Koordinat } & \multirow{2}{*}{ Alamat } & \multirow{2}{*}{ Kecamatan } \\
\hline & & & $\mathrm{X}(\mathrm{m})$ & $\mathrm{Y}(\mathrm{m})$ & & \\
\hline 1 & Klinik Polresta Samarinda & BPJS & 513198.804 & 9944580.836 & Jl. Cendana & Sungai Kunjang \\
\hline 2 & $\begin{array}{l}\text { Klinik DENKESYAH } \\
\text { KOREM Samarinda }\end{array}$ & BPJS & 515858.089 & 9944641.186 & Jl. Awang Long & Samarinda Kota \\
\hline 3 & Klinik Islamic Center & BPJS & 513198.804 & 9944580.836 & J1. Cendana & Sungai Kunjang \\
\hline 4 & $\begin{array}{l}\text { Klinik Kimia Farma Dr. } \\
\text { Sutomo }\end{array}$ & BPJS & 516327.163 & 9947210.033 & Jl. Dr. Sutomo & Samarinda Kota \\
\hline 5 & Klinik Kimia Farma Amanah & BPJS & 517339.732 & 9950204.775 & J1. PM. Noor & Samarinda Utara \\
\hline 6 & $\begin{array}{l}\text { Klinik Kimia Farma } \\
\text { Hidayatullah }\end{array}$ & BPJS & 517315.690 & 9944519.088 & $\begin{array}{l}\text { Gg. Karya } 2 \text { Karang } \\
\text { Mumus }\end{array}$ & Samarinda Kota \\
\hline 7 & Klinik Kumala Antasari & BPJS & 514170.474 & 9945698.970 & Jl. Siradj Salman & Samarinda Ulu \\
\hline 8 & Klinik Dr. G. Wilsa & BPJS & 517067.083 & 9951469.392 & Jl. Padat Karya & Samarinda Utara \\
\hline 9 & $\begin{array}{l}\text { Klinik Mahakam Medika } \\
\text { Palaran Samarinda }\end{array}$ & BPJS & 523499.329 & 9935754.260 & Gg. Kenangan Palaran & Palaran \\
\hline 10 & Klinik Aminah Amin & BPJS & 518606.427 & 9946170.533 & Jl. Merdeka 1 & Sungai Pinang \\
\hline 11 & Klinik FK Unmul & BPJS & 517370.395 & 9948359.925 & Universitas Mulawarman & Samarinda Ulu \\
\hline 12 & Klinik Illa Medika Trikora & BPJS & 518748.018 & 9938293.602 & J1. Trikora & Palaran \\
\hline 13 & Klinik Mitra Gustiana & BPJS & 514074.895 & 9945739.290 & Jl. Pangeran Antasari & Samarinda Ulu \\
\hline 14 & $\begin{array}{l}\text { Klinik Mitra Keluarga Wahid } \\
\text { Hasyim }\end{array}$ & BPJS & 516758.837 & 9948875.958 & Jl. Wahid Hasyim I & Samarinda Utara \\
\hline 15 & Klinik Media Farma & BPJS & 517599.959 & 9945776.828 & J1. Lambung Mangkurat & Samarinda Ilir \\
\hline 16 & Klinik Medika Meta Utama & BPJS & 516695.721 & 9949192.130 & Jl. Wahid Hasyim I & Samarinda Utara \\
\hline 17 & Klinik Tata Medika Air Hitam & BPJS & 515461.598 & 9948452.163 & Jl. A. Wahab Syahranie & Samarinda Ulu \\
\hline 18 & Klinik Sentra Medika & BPJS & 517367.643 & 9947078.235 & Jl. Jenderal Ahmad Yani I & Sungai Pinang \\
\hline 19 & Klinik Ramlah Parjib I & BPJS & 516828.443 & 9946762.559 & Jl. A.M Sangaji & Sungai Pinang \\
\hline 20 & Klinik Pratama Etam & BPJS & 517819.029 & 9944466.158 & Jl. Jelawat & Samarinda Ilir \\
\hline 21 & Klinik Pratama Satya Prima & BPJS & 516269.303 & 9947353.333 & J1. Dr. Sutomo & Samarinda Ulu \\
\hline 22 & $\begin{array}{l}\text { Klinik Kimia Farma DI. } \\
\text { Panjaitan }\end{array}$ & BPJS & 521011.414 & 9949339.663 & Jl. DI Panjaitan & Sungai Pinang \\
\hline 23 & Klinik Nur Asih Kadri Oneng & BPJS & 514231.248 & 9947784.346 & Jl. Kadrie Oening & Samarinda Ulu \\
\hline 24 & $\begin{array}{l}\text { Klinik Sehat Bersama Sinatra } \\
\text { Ampera }\end{array}$ & BPJS & 519712.413 & 9936763.289 & J1. Ampera & Palaran \\
\hline 25 & Klinik 88 Harun Nafsi & BPJS & 515372.304 & 9942159.951 & Jl. KH. Harun Nafsi & Loa Janan Ilir \\
\hline 26 & Klinik Sabena & BPJS & 514077.887 & 9946105.078 & Jl. Pangeran Antasari & Samarinda Ulu \\
\hline 27 & Klinik Hj Ninik Kustiani 1 & BPJS & 516383.908 & 9942302.003 & Jl. SMPN 8 Jl. Pattimura & $\begin{array}{l}\text { Samarinda } \\
\text { Seberang } \\
\end{array}$ \\
\hline 28 & Klinik Yarsi & BPJS & 517686.951 & 9943927.170 & Jl. Gurami & Samarinda Ilir \\
\hline 29 & Klinik Ria Kencana PKBI & BPJS & 515822.116 & 9947719.243 & Jl. Letnan Jend. Suprapto & Samarinda Ulu \\
\hline 30 & Klinik Ramlah Parjib 2 & BPJS & 516828.443 & 9946762.559 & Jl. A.M Sangaji & Sungai Pinang \\
\hline 31 & Klinik Aminah Riantah & BPJS & 518755.019 & 9947677.859 & Jl. Nusantara & Sungai Pinang \\
\hline 32 & Klinik Cahaya Husada Kaltim & BPJS & 517991.535 & 9952629.077 & J1. Bengkuring Raya & Samarinda Utara \\
\hline 33 & Klinik Ramlah Parjib 3 & BPJS & 521470.486 & 9948381.835 & Jl. Mugirejo & Sungai Pinang \\
\hline 34 & Klinik Mahkota Samarinda & BPJS & 518212.860 & 9942428.803 & Gg. Masjid Syifa Selili & Samarinda Ilir \\
\hline 35 & Klinik Kimia Farma M. Said & BPJS & 512515.700 & 9945438.268 & Jl. Moh. Said & Sungai Kunjang \\
\hline 36 & $\begin{array}{l}\text { Klinik Kimia Farma } \\
\text { Sambutan }\end{array}$ & BPJS & 518449.528 & 9943723.598 & Jl. Sultan Alimuddin & Sambutan \\
\hline 37 & Klinik Kusuma Samarinda & BPJS & 517753.897 & 9949470.294 & Jl. Perjuangan 7 & Samarinda Utara \\
\hline 38 & Klinik Ibnu Rusyd & BPJS & 513312.990 & 9948263.435 & Jl. P. Suryanata & Samarinda Ulu \\
\hline 39 & Klinik Spesialis Mata SMEC & BPJS & 515861.361 & 9947676.108 & Jl. Kemang & Samarinda Ulu \\
\hline 40 & $\begin{array}{l}\text { Klinik Matahari Bhakti } \\
\text { Husada }\end{array}$ & BPJS & 516913.999 & 9945626.541 & Jl. KH. Agus Salim & Samarinda Kota \\
\hline 41 & Klinik Rama Medika & Non BPJS & 516480.604 & 9942207.580 & J1. Pattimura & $\begin{array}{l}\text { Samarinda } \\
\text { Seberang }\end{array}$ \\
\hline 42 & Klinik Alysaa & Non BPJS & 517628.383 & 9944071.878 & Jl. Kakap & Samarinda Ilir \\
\hline 43 & Klinik Darul Hayyi & Non BPJS & 512192.381 & 9944240.006 & Jl. Rapak Indah & Sungai Kunjang \\
\hline 44 & $\begin{array}{l}\text { Klinik Semoga Sehat } \\
\text { Darussalam }\end{array}$ & Non BPJS & 516479.385 & 9944337.343 & Jl. Yos Sudarso & Samarinda Kota \\
\hline 45 & Klinik Finar & Non BPJS & 516448.934 & 9945585.974 & Jl. GOR Segiri & Samarinda Kota \\
\hline 46 & Klinik Kellyn Medika & Non BPJS & 516911.939 & 9945263.161 & Jl. Danau Toba & Samarinda Kota \\
\hline 47 & Klinik Kartika Jaya & Non BPJS & 518341.132 & 9945863.820 & Jl. Merdeka 3 & Sungai Pinang \\
\hline 48 & Klinik Prodia & Non BPJS & 517672.220 & 9947307.055 & Jl. Jenderal Ahmad Yani I & Sungai Pinang \\
\hline 49 & Klinik Immanuel & Non BPJS & 515535.248 & 9948766.035 & Jl. A. Wahab Syahranie & Samarinda Ulu \\
\hline
\end{tabular}




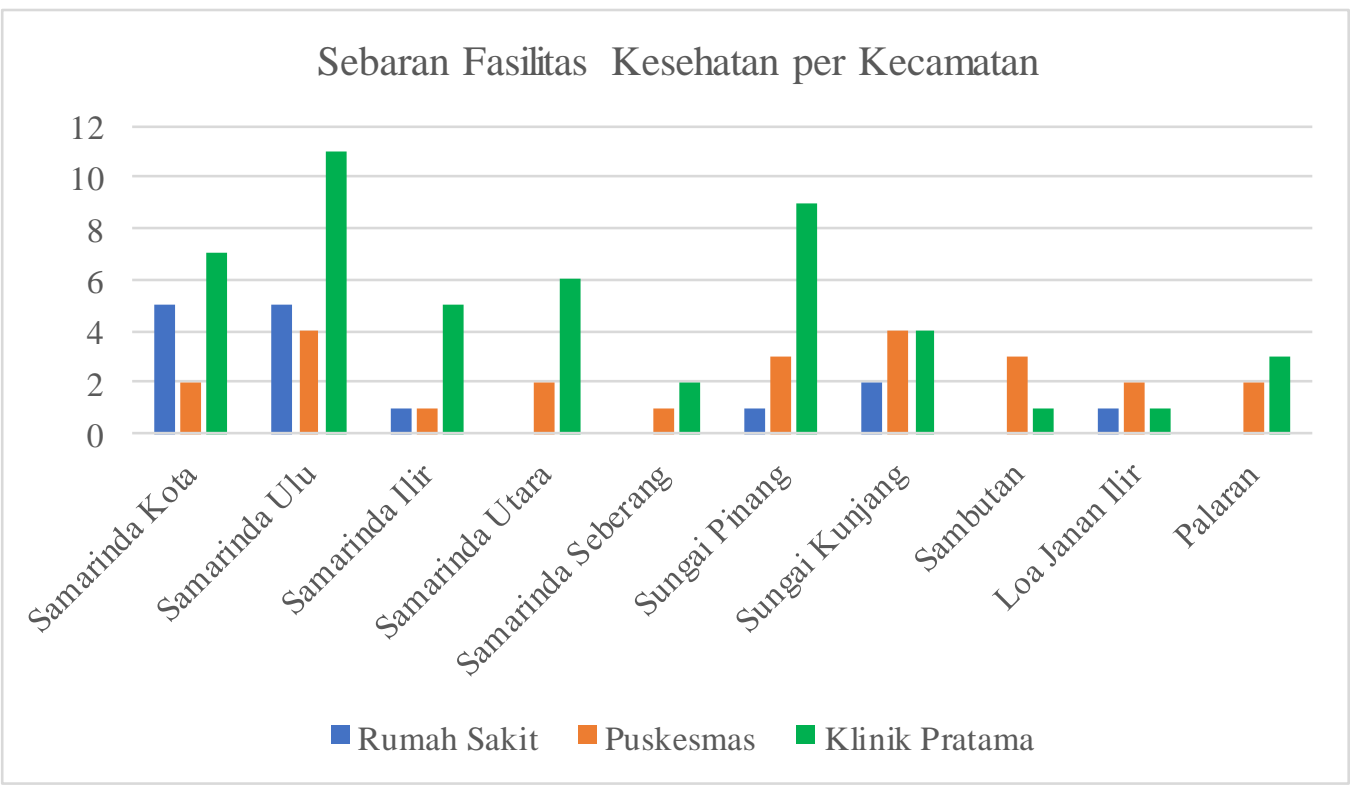

Gambar 2. Sebaran Fasilitas Kesehatan Kota Samarinda per Kecamatan

Berdasarkan diagram pada Gambar 2, keberadaan fasilitas kesehatan paling banyak ada di Kecamatan Samarinda Ulu, Kecamatan Sungai Pinang dan Kecamatan Samarinda Kota. Sebaran 15 Rumah Sakit yang ada di Kota Samarinda adalah Samarinda Kota dengan 5 Rumah Sakit (1 diantaranya tidak melayani peserta BPJS), Samarinda Ulu dengan 5 Rumah Sakit (1 diantaranya tidak melayani peserta BPJS), Sungai Kunjang dengan 2 Rumah Sakit (1 diantaranya tidak melayani peserta BPJS), dan 1 Rumah Sakit masingmasing pada Kecamatan Samarinda Ilir, Sungai Pinang, dan Loa Janan Ilir.

Keberadaan 24 Puskesmas yang seluruhnya melayani peserta BPJS tersebar di seluruh Kecamatan, 4 Puskesmas masing-masing di Kecamatan Samarinda Ulu dan Sungai Kunjang, 3 Puskesmas masing-masing di Kecamatan Sungai Pinang dan Sambutan, 2 Puskesmas masing-masing di Kecamatan Samarinda Kota, Samarinda Utara, Loa Janan Ilir, dan Palaran. Kecamatan Samarinda Ilir dan Samarinda Seberang masing-masing terdapat 1 Puskesmas.

Kecamatan dengan sebaran Klinik Pratama terbanyak adalah Kecamatan Samarinda Ulu dengan 11 Klinik Pratama (1 diantaranya tidak melayani peserta BPJS), dan 9 Klinik Pratama di Kecamatan Sungai Pinang (2 diantaranya tidak melayani peserta BPJS). Kecamatan Samarinda Kota dengan 7 Klinik Pratama (3 diantaranya tidak melayani peserta BPJS), Samarinda Utara dengan 6 Klinik Pratama, Samarinda Ilir dengan 5 Klinik Pratama (1 diantaranya tidak melayani peserta BPJS), Sungai Kunjang dengan 4 Klinik Pratama (1 diantaranya tidak melayani peserta BPJS), Palaran dengan 3 Klinik Pratama, Samarinda Seberang dengan 2 Klinik Pratama (1 diantaranya tidak melayani peserta BPJS), dan Kecamatan Sambutan dan Loa Janan Ilir dengan masingmasing 1 Klinik Pratama.

Sebaran fasilitas kesehatan yang ada di Kota Samarinda secara spasial pada masing-masing kecamatan menunjukkan bahwa masih ada kecenderungan berkumpul pada Kecamatan dengan kepadatan penduduk tinggi. Beberapa kecamatan walaupun memiliki luas wilayah yang tinggi tidak tidak menjamin keberadaan fasilitas kesehatannya juga tinggi. Secara rinci kenampakan spasial dari sebaran fasilitas kesehatan di Kota Samarinda disajikan dalam bentuk peta pada Gambar 3 sampai dengan Gambar 12.

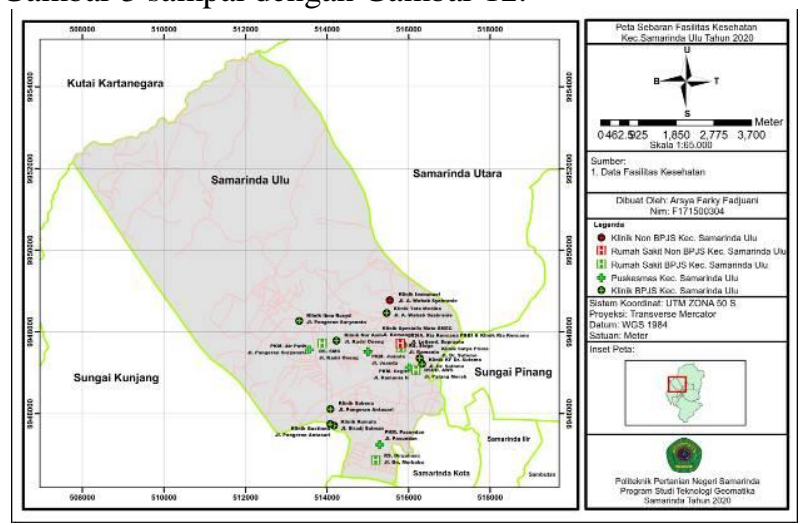

Gambar 3. Peta Sebaran Fasilitas Kesehatan Kecamatan Samarinda Ulu

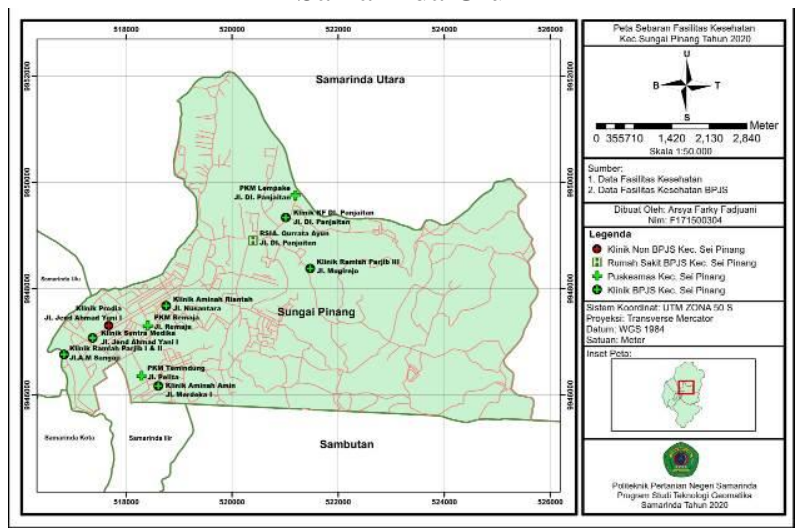

Gambar 4. Peta Sebaran Fasilitas Kesehatan Kecamatan Sungai Pinang 


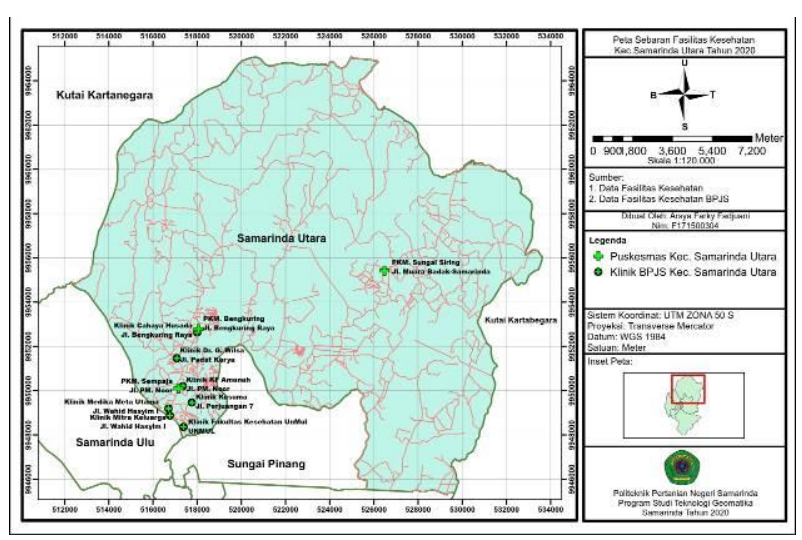

Gambar 5. Peta Sebaran Fasilitas Kesehatan Kecamatan Samarinda Utara

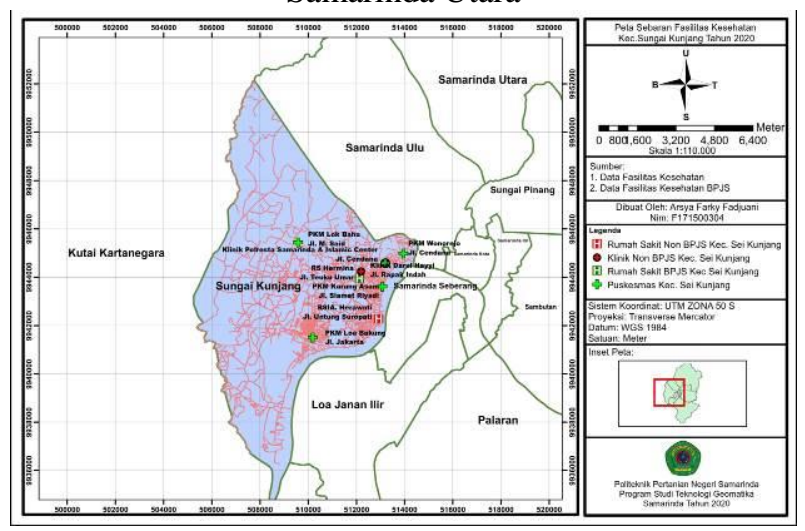

Gambar 6. Peta Sebaran Fasilitas Kesehatan Kecamatan Sungai Kunjang

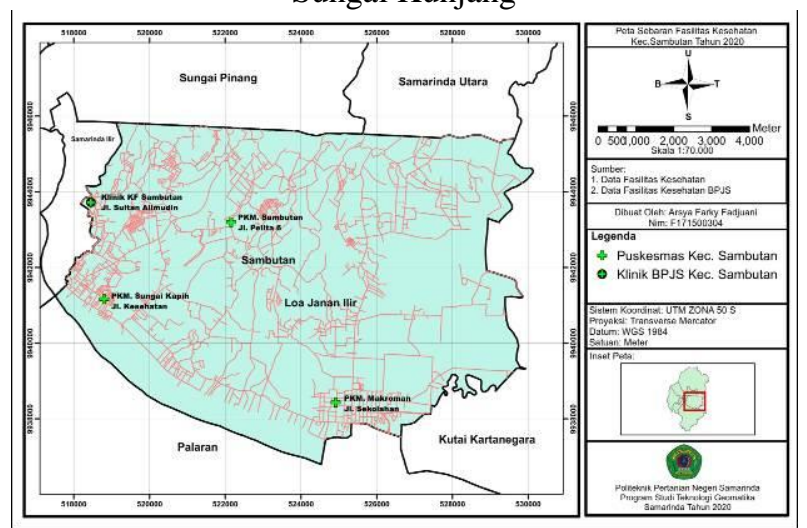

Gambar 7. Peta Sebaran Fasilitas Kesehatan Kecamatan Sambutan

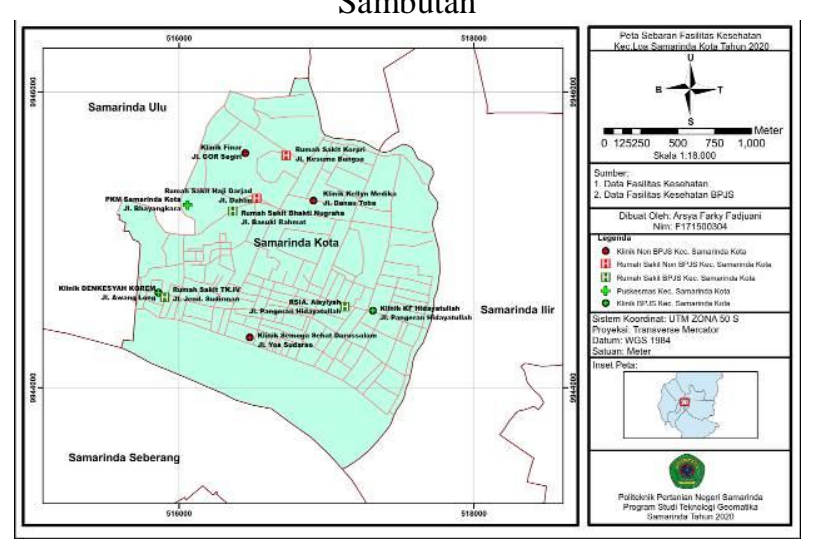

Gambar 8. Peta Sebaran Fasilitas Kesehatan Kecamatan Samarinda Kota

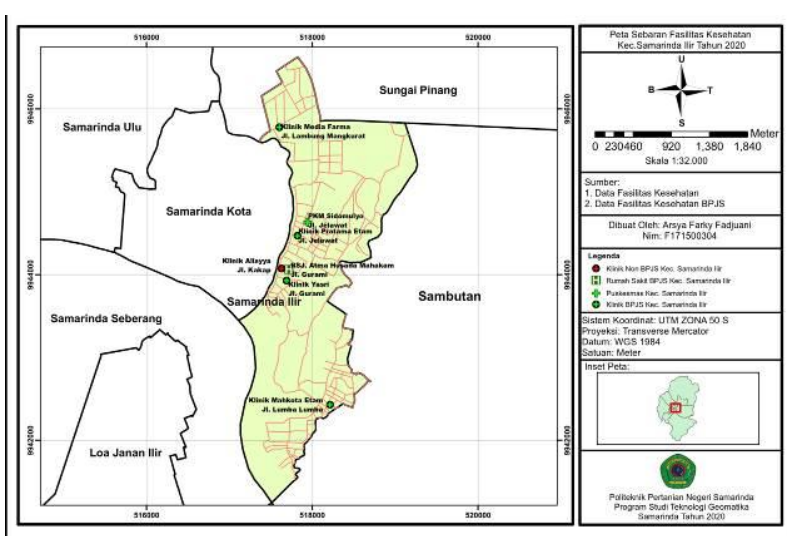

Gambar 9. Peta Sebaran Fasilitas Kesehatan Kecamatan Samarinda Ilir

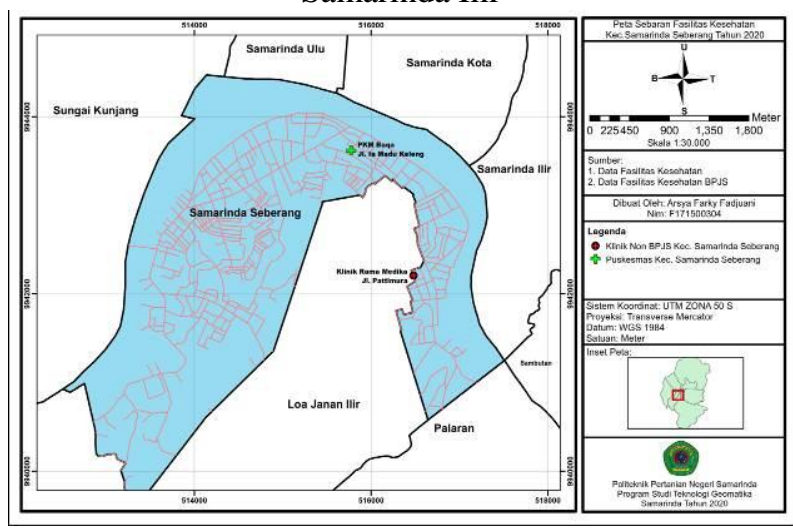

Gambar 10. Peta Sebaran Fasilitas Kesehatan Kecamatan Samarinda Seberang

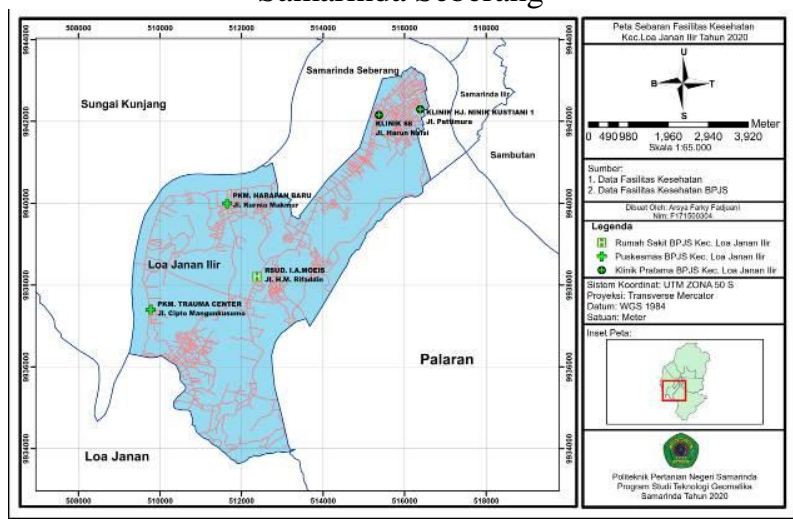

Gambar 11. Peta Sebaran Fasilitas Kesehatan Kecamatan Loa Janan Ilir

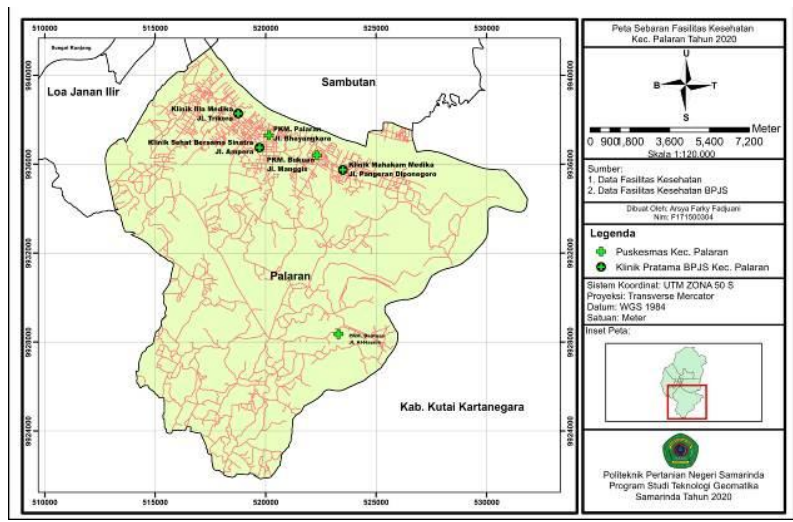

Gambar 12. Peta Sebaran Fasilitas Kesehatan Kecamatan Palaran 


\section{KESIMPULAN}

Berdasarkan hasil penelitian tentang pemetaan fasilitas kesehatan yang ada di Kota Samarinda yang dilaksanakan dapat disimpulkan bahwa terdapat 15 Rumah Sakit dengan 12 diantaranya melayani pasien peserta BPJS dan 3 Rumah Sakit tidak melayani pasien peserta BPJS, 24 Puskesmas seluruhnya melayani pasien peserta BPJS, dan 49 Klinik Pratama dengan 40 diantaranya melayani pasien peserta BPJS dan 9 Klinik Pratama melayani pasien peserta BPJS. Secara spasial, sebaran fasilitas kesehatan tidak merata ke seluruh kecamatan dan masih terpusat pada wilayah kecamatan dengan tingkat kepadatan penduduk tinggi dan pada pusat-pusat kegiatan masyarakat seperti perkantoran, dan sarana Pendidikan.

\section{DAFTAR PUSTAKA}

Anonim. (2020). Indeks Penduduk Kota Samarinda Tahun 2020. BPS Kota Samarinda. https://samarindakota.bps.go.id/

Anonim. (2021). Permenkes 43 tahun 2019 tentang Puskesmas. Jogloabang. https://www.jogloabang.com/kesehatan/permenkes43-2019-puskesmas

Dani, M. F. (2017). Persebaran Rumah Sakit di Kota Samarinda Berbasis Website. Politeknik Pertanian Negeri Samarinda.
Endradita, G. (2019). Fasilitas Pelayanan Kesehatan. https://galihendradita.wordpress.com/2019/11/01/fasil itas-pelayanan-kesehatan/

Melya, A. (2017). Analisis dan Pemetaan Sebaran Fasilitas Kesehatan di Kabupaten Lampung Barat. Universitas Lampung.

Permenkes. (2019). Peraturan Menteri Kesehatan No 30 Tahun 2019 Tentang Klasifikasi dan Perizinan Rumah Sakit. Menteri Kesehatan.

PKFI. (2014). Peraturan Klinik. Perhimpunan Klinik Medis Indonesia. https://www.pkfi.net/page/view/18_peraturan_klinik

Putri, F. L. B., Najoan, X. B. N., \& Rindengan, Y. D. . (2017). Sistem Informasi Pemetaan Fasilitas Kesehatan BPJS Berbasis Android di Kota Bitung. Jurnal Teknik Informatika, 11(1), 1-8. https://doi.org/10.35793/jti.11.1.2017.16923

Rahardjo, D. S., \& Sugiyanto. (2015). Sistem Informasi Geografis Pemetaan Fasilitas Kesehatan pada BPJS Kota Semarang. Techno.COM, 14(02), 135-144.

Rita. (2012). Sistem Informasi Geografis Puskesmas Induk Kota Samarinda. Politeknik Pertanian Negeri Samarinda. 